\title{
Actin-binding protein ABP140 is a methyltransferase for 3-methylcytidine at position 32 of tRNAs in Saccharomyces cerevisiae
}

\author{
AKIKO NOMA, ${ }^{1}$ SANGHYUN YI, ${ }^{1}$ TAKAYUKI KATOH, ${ }^{1}$ YOSHIMI TAKAI, ${ }^{2}$ TAKEO SUZUKI, ${ }^{1}$ \\ and TSUTOMU SUZUKI ${ }^{\mathbf{1}}$ \\ ${ }^{1}$ Department of Chemistry and Biotechnology, Graduate School of Engineering, University of Tokyo, Bunkyo-ku, Tokyo 113-8656, Japan \\ ${ }^{2}$ Division of Molecular and Cellular Biology, Department of Biochemistry and Molecular Biology, Kobe University Graduate School of Medicine/ \\ Faculty of Medicine, Kobe, Hyogo, Japan
}

\begin{abstract}
Transfer RNAs contain various modified nucleotides that are introduced enzymatically at the post-transcriptional level. In Saccharomyces cerevisiae, 3-methylcytidine $\left(\mathrm{m}^{3} \mathrm{C}\right)$ is found at position 32 of the tRNAs for Thr and Ser. We used a systematic reverse genetic approach combined with mass spectrometry (ribonucleome analysis), and identified the actin-binding protein $A B P 140$ as the protein responsible for $m^{3} \mathrm{C}$ formation in both $t R N A^{T h r 1}$ and $t R N A^{\text {Ser1 }}$. ABP140 consists of an N-terminal actinbinding sequence and a C-terminal S-adenosylmethionine (Ado-Met) binding motif. Deletion of the actin-binding sequence in ABP140 did not affect $\mathrm{m}^{3} \mathrm{C}$ formation, indicating that subcellular localization of ABP140 to actin filaments is not involved in tRNA modification. $\mathrm{m}^{3} \mathrm{C}$ formation in $\mathrm{tRNA}^{\mathrm{Thr} 1}$ could be reconstituted using recombinant Abp140p in the presence of Ado-Met, whereas $\mathrm{m}^{3} \mathrm{C}$ did not form in $\mathrm{tRNA}{ }^{\mathrm{Ser} 1}$ in vitro, indicating the absence of a factor(s) required for $\mathrm{tRNA} \mathrm{m}^{\mathrm{Ser} 1} \mathrm{~m}^{3} \mathrm{C}$ formation. Thus, $A B P 140$ has been designated TRM140 according to the preferred nomenclature. In addition, we observed a specific reduction of $\mathrm{m}^{3} \mathrm{C}$ formation in HeLa cells by siRNA-mediated knock down of the human ortholog of TRM140.
\end{abstract}

Keywords: 3-methylcytidine; ABP140; S-adenosylmethionine; TRM140; tRNA

\section{INTRODUCTION}

RNA modifications play pivotal roles in the biogenesis, metabolism, structural stability, and functions of RNA molecules. To date, more than 100 chemically different, site-specific RNA modifications have been identified (Dunin-Horkawicz et al. 2006; Cantara et al. 2011). The majority of RNA modifications occur in tRNAs (Juhling et al. 2009). In particular, a wide variety of modifications in the anticodon loop of tRNAs facilitate the efficient and accurate recognition of cognate codons, and are therefore integral in protein synthesis (Bjork 1995; Curran 1998; Suzuki 2005; Agris et al. 2007).

3-methylcytidine $\left(\mathrm{m}^{3} \mathrm{C}\right)$ (Fig. 1A) was first isolated in 1963 from soluble yeast RNA (Hall 1963). $\mathrm{m}^{3} \mathrm{C}$ is found in both eukaryotic rRNAs and tRNAs (Iwanami and Brown

Reprint requests to: Tsutomu Suzuki, Department of Chemistry and Biotechnology, Graduate School of Engineering, University of Tokyo, Bunkyo-ku, Tokyo 113-8656, Japan; e-mail: ts@chembio.t.u-tokyo.ac.jp; fax: 81-3-5841-0550.

Article published online ahead of print. Article and publication date are at http://www.rnajournal.org/cgi/doi/10.1261/rna.2653411.
1968; Maden and Salim 1974). In Saccharomyces cerevisiae, $\mathrm{m}^{3} \mathrm{C}$ is located at position 32 of tRNA ${ }^{\text {Thrl }}$ and tRNA ${ }^{\text {Ser1 }}$ (Fig. 1B; Weissenbach et al. 1977; Olson et al. 1981). In the anticodon loop of tRNAs, residues at position 32 at the $5^{\prime}$ end of the anticodon loop are nearly conserved as pyrimidines $(\mathrm{Y}=\mathrm{U} / \mathrm{C})$. Y32 forms a noncanonical base pair with the residue at position 38 (Olejniczak and Uhlenbeck 2006), which is most frequently adenosine. It has been proposed that the structure of the Y32-A38 pair is essential for the U-turn conformation of the anticodon loop. A U32C mutation in Escherichia coli tRNA ${ }^{\text {Gly }}$ resulted in tighter binding to both cognate and near-cognate codons at the A-site of the ribosome (Lustig et al. 1993). Similarly, misincorporation of Ala at the near cognate GUC codon was caused by tRNA $^{\mathrm{Ala}}$ with mutations of base pairs at positions 32 and 38 (Murakami et al. 2009). These observations clearly suggest the importance of the Y32-A38 pair of aminoacyl-tRNAs for uniform and accurate codon recognition at the A-site (Olejniczak and Uhlenbeck 2006). At the P-site of the ribosome, the C-terminal tail of the ribosomal protein S9 contacts residues 32-34 of peptidyl-tRNAs (Korostelev and 


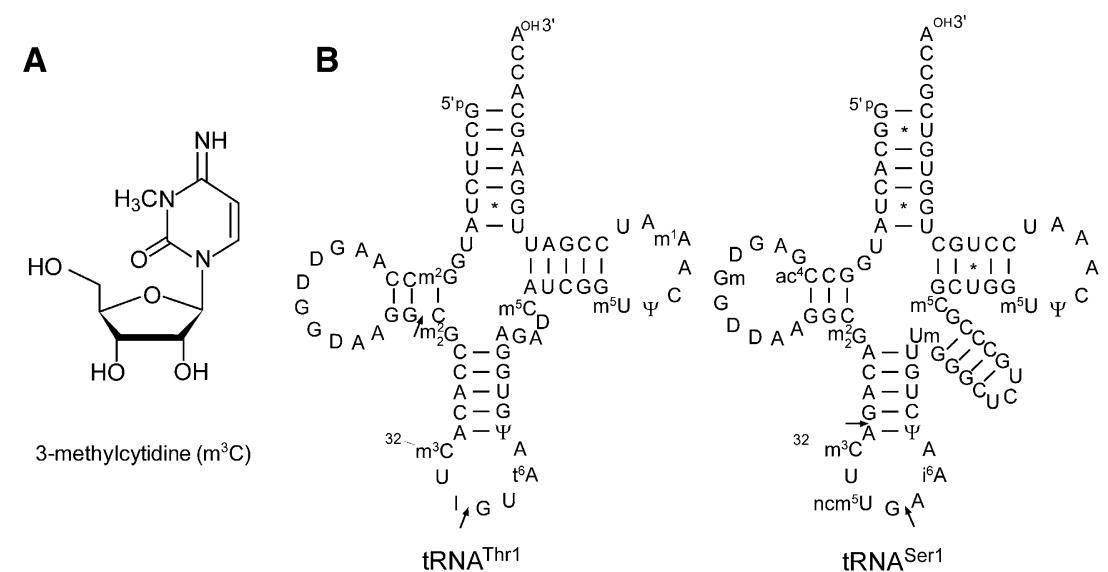

FIGURE 1. The chemical structure of 3-methylcytidine and its position in tRNA ${ }^{\text {Thr1 }}$ and tRNA ${ }^{\text {Ser1 }}$. (A) Chemical structure of 3-methylcytidine $\left(\mathrm{m}^{3} \mathrm{C}\right)$. (B) Secondary structures of S. cerevisiae tRNA ${ }^{\text {Thr1 }}$ and tRNA ${ }^{\text {Serl }}$ with modified nucleosides: 3-methylcytidine $\left(\mathrm{m}^{3} \mathrm{C}\right)$, $N^{2}$-methylguanosine $\left(\mathrm{m}^{2} \mathrm{G}\right)$, dihydrouridine (D), $N^{2}, N^{2}$-dimethylguanosine $\left(\mathrm{m}_{2}^{2} \mathrm{G}\right)$, inosine (I), $N^{6}$-threonylcarbamoyladenosine $\left(\mathrm{t}^{6} \mathrm{~A}\right)$, pseudouridine $(\Psi), 5$-methylcytidine $\left(\mathrm{m}^{5} \mathrm{C}\right)$, 5-methyluridine $\left(\mathrm{m}^{5} \mathrm{U}\right)$, 1-methyladenosine $\left(\mathrm{m}^{1} \mathrm{~A}\right), N^{4}$-acetylcytidine $\left(\mathrm{ac}^{4} \mathrm{C}\right), 2^{\prime}$-O-methylguanosine $(\mathrm{Gm}), 5$-carbamoylmethyluridine $\left(\mathrm{ncm}^{5} \mathrm{U}\right), N^{6}$-isopentenyladenosine $\left(\mathrm{i}^{6} \mathrm{~A}\right)$, and $2^{\prime}$-O-methyluridine $(\mathrm{Um})$. Arrows indicate sites of RNase $\mathrm{T}_{1}$ cleavage to generate RNA fragments containing residues at position 32 .

Noller 2007; Nasvall et al. 2009). Aberrant interaction between the C-terminal tail of $\mathrm{S} 9$ and residue 32 resulted in an increase in +1 frameshifting, indicating that the correct recognition of residue 32 by $S 9$ has a critical role in readingframe maintenance. Despite the functional importance of position 32, little is known about $\mathrm{m}^{3} \mathrm{C} 32$. Methyl modification of $\mathrm{m}^{3} \mathrm{C} 32$ might modulate accurate codon recognition at the A-site and the proper ribosomal positioning at the P-site. To investigate the functional roles of $\mathrm{m}^{3} \mathrm{C}$, it will be necessary to identify the gene or enzyme responsible for this modification.

To explore the genes responsible for tRNA and rRNA modifications, our group has developed a genome-wide screen using a reverse genetic approach combined with mass spectrometry, which we call "ribonucleome analysis" (Suzuki 2005; Suzuki et al. 2007). This analysis utilizes a knockout strain collection of S. cerevisiae (or E. coli). Total RNA extracted from each strain is analyzed by liquid chromatography/mass spectrometry (LC/MS) to determine whether deletion of a particular gene leads to the absence of a specific modified nucleoside, thereby permitting us to identify the enzyme or protein responsible for the modification. In the case of essential genes, temperature-sensitive mutants were cultured at the nonpermissive temperature, or expression-controlled strains were used (Soma et al. 2003). Ribonucleome analysis allows us to identify not only the enzymes directly responsible for RNA modifications, but also genes that encode proteins that lack enzymatic activity but are necessary for RNA modifications. These include carriers of the metabolic substrates used for RNA modifications and partner proteins needed for RNA recognition. Using this approach in yeast, we identified and characterized TYW1-4 for wybutosine (Noma et al. 2006) and URM1, UBA4, NCS2, NCS6, and TUM1 for 2-thiouridine in S. cerevisiae (Noma et al. 2009).

In this study we utilized ribonucleome analysis to determine the enzyme responsible for $\mathrm{m}^{3} \mathrm{C}$ formation in $\mathrm{tRNA}{ }^{\text {Thr1 }}$ and tRNA ${ }^{\text {Ser1 }}$, and identified $A B P 140$, which encodes an actin-binding protein with previously unknown function (Asakura et al. 1998).

\section{RESULTS}

\section{Genome-wide screening for the gene responsible for $\mathrm{m}^{3} \mathrm{C}$ formation by ribonucleome analysis}

To explore the genes responsible for tRNA modifications, including $\mathrm{m}^{3} \mathrm{C}$ in S. cerevisiae, ribonucleome analysis was performed (Suzuki et al. 2007). Assuming that the gene responsible for $\mathrm{m}^{3} \mathrm{C}$ formation was nonessential, 4829 nonessential genes in S. cerevisiae were examined as a parent population for screening. Because $\mathrm{m}^{3} \mathrm{C}$ is also found in Schizosaccharomyces pombe, 3482 genes were selected for study, the orthologs of which are present in S. pombe. Finally, 351 genes whose ORFs were described as proteins of unknown function in S. cerevisiae (CYGD: http://mips.gsf.de/ genre/proj/yeast) (Guldener et al. 2005) were chosen for ribonucleome analysis. In the mass chromatogram (Fig. 2A), $\mathrm{m}^{3} \mathrm{C}$ was detected as a proton adduct form $\left(\mathrm{MH}^{+} ; \mathrm{m} / \mathrm{z} 258\right)$ in wild-type cells. Among the 351 haploid knockout strains, the yor $240 w \Delta$ was identified as a strain in which $\mathrm{m}^{3} \mathrm{C}$ was absent (Fig. 2A). YOR240w encodes the latter half of a long gene named $A B P 140$ (Fig. 3A). ABP140 was reported as a fused gene of YOR239w and YOR240w by connecting with the +1 frameshift site at the junction of these two genes (Asakura et al. 1998). We next examined the yor239w $\Delta$ strain, which lacks the former half of this gene (Fig. 3A) and found the absence of $\mathrm{m}^{3} \mathrm{C}$ (Fig. 2A). We also constructed an abp1404 strain that lacks the entire $A B P 140$ gene. As expected, $\mathrm{m}^{3} \mathrm{C}$ was absent in the abp140A strain (Fig. 2A). Levels of other detectable nucleosides were normal in these strains (data not shown).

\section{Absence of $m^{3} \mathrm{C}$ at position 32 in tRNA ${ }^{\mathrm{Th} 1}$ and $\mathrm{TRNA} \mathrm{Aer}^{\text {Ser }}$}

To confirm the absence of $\mathrm{m}^{3} \mathrm{C}$ at position 32 of individual tRNAs, tRNA ${ }^{\text {Thr1 }}$ and tRNA $^{\text {Ser1 }}$ were isolated from both wild-type and yor240w $\Delta$ strains. The absence of $\mathrm{m}^{3} \mathrm{C}$ in both tRNAs isolated from yor240w $\Delta$ strain was confirmed by nucleoside analysis using LC/MS (Supplemental Fig. 1). Next, each tRNA was digested into RNA fragments by 
A

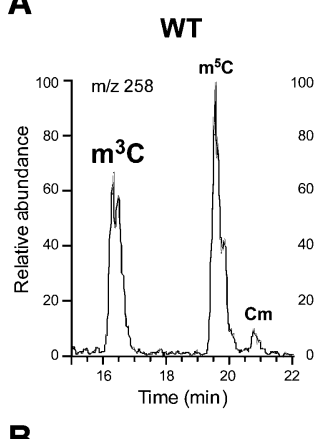

B
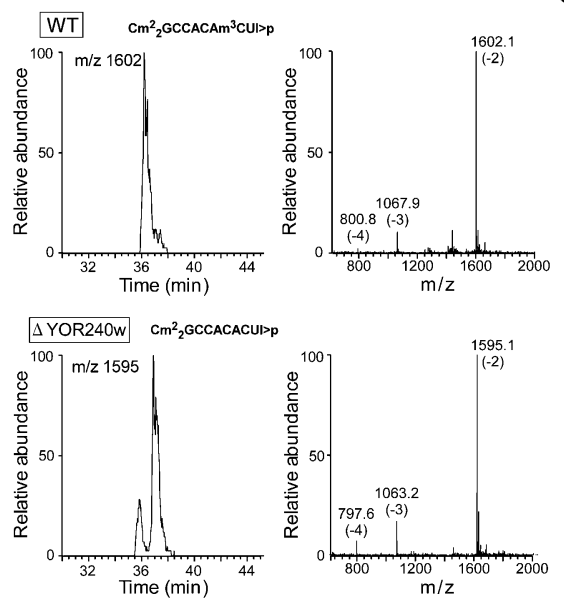

$\triangle$ YOR239w $\triangle$ YOR240w

$\triangle \mathrm{ABP} 140$

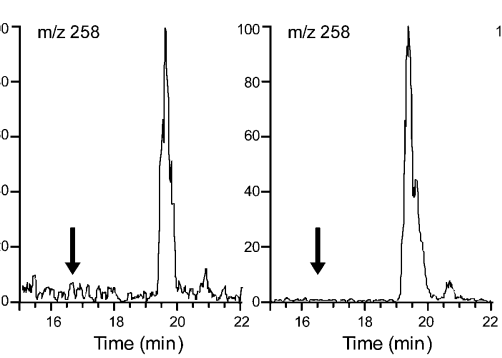

C
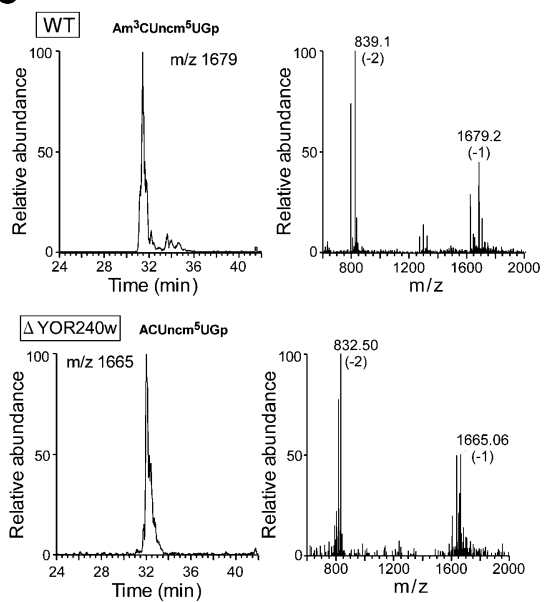

FIGURE 2. Mass spectrometric analysis of total nucleosides and individual tRNAs from $S$. cerevisiae wild-type and mutant cells. (A) LC/MS analysis of total nucleosides from strains of

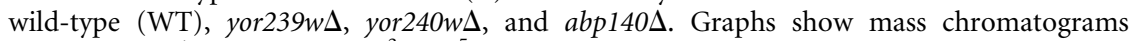
traced by $\mathrm{MH}^{+}(\mathrm{m} / \mathrm{z} 258)$ of $\mathrm{m}^{3} \mathrm{C}, \mathrm{m}^{5} \mathrm{C}$, and $2^{\prime}-O$-methylcytidine $(\mathrm{Cm})$. Arrows indicate the retention time for $\mathrm{m}^{3} \mathrm{C}$. $(B, C)$ CapLC/nanoESI MS analysis of RNase $\mathrm{T}_{1}$-digested tRNA ${ }^{\mathrm{Thr} 1}(B)$ or tRNA ${ }^{\text {Ser1 }}(C)$ isolated from wild-type (top) and yor240ws (bottom) strains. (Left) The mass chromatograms traced by doubly charged ions of fragments bearing $\mathrm{m}^{3} \mathrm{C} 32(\mathrm{~m} / \mathrm{z} 1602[B]$ or $1679[C])$ and $\mathrm{C} 32(\mathrm{~m} / \mathrm{z} 1595[B]$ or $1665[C])$. (Right) The mass spectra of position 32 containing fragments. The charge states of multiply charged ions are indicated in parentheses. The RNA sequences of each fragment are indicated on each graph. " $>p$ " at the 3 ' end of the fragment indicates cyclic phosphate. "Relative abundance" for $y$-axis of mass chromatograms and mass spectra shown in this figure and Figures 4, 5, and 6 stands for the percentile presentation of peak intensities that were normalized, with the highest peak defined as 100 .

RNase $\mathrm{T}_{1}$ and analyzed by capillary liquid chromatography nano electrospray mass spectrometry (CapLC/nanoESI MS) (Suzuki et al. 2007; Ikeuchi et al. 2010). In wild-type tRNA ${ }^{\text {Thr1 }}$, the RNA fragment containing position 32, $\mathrm{Cm}_{2}^{2}$ GCCACAm ${ }^{3} \mathrm{CUI}>\mathrm{p}$ (MW 3206.4), was detected as doubly, triply, and quadruply charged ions $(\mathrm{m} / \mathrm{z}$ 1602.1, $\mathrm{m} / \mathrm{z}$ 1067.9, and $\mathrm{m} / \mathrm{z}$ 800.8) as expected (Fig. 2B). The equivalent RNA fragment in tRNA ${ }^{\text {Thr1 }}$ isolated from the yor240w $\Delta$ strain was detected as $\mathrm{m} / \mathrm{z} 1595.1$ (a doubly charged ion) with a MW of 3192.4, which exactly matched with the molecular mass of the RNA fragment with C32 $\left(\mathrm{Cm}_{2}^{2}\right.$ GCCACACUI $\left.>\mathrm{p}\right)$. In wild-type tRNA ${ }^{\text {Ser1 }}$, the wobble base has not yet been reported (Olson et al. 1981). Therefore, nucleoside analysis was performed, which resulted in the identification of the wobble base as 5-carbamoylmethyluridine $\left(\mathrm{ncm}^{5} \mathrm{U}\right)$ (Fig. 1B; Supplemental Fig. 1). The
RNA fragment containing position 32, $\mathrm{Am}^{3} \mathrm{CUncm}{ }^{5} \mathrm{UGp}$ (MW 1680.2), was detected as singly and doubly charged ions (m/z 1679 and $\mathrm{m} / \mathrm{z}$ 839) (Fig. 2B). The equivalent RNA fragment in tRNA ${ }^{\text {Serl }}$ isolated from the yor240w $\Delta$ strain was detected as $\mathrm{m} / \mathrm{z} 1665$ (MW 1666.2), which corresponded to the molecular mass of the RNA fragment with C32 (ACUncm ${ }^{5} \mathrm{UGp}$ ). To confirm this result, primer extension analysis was performed to verify the absence of $\mathrm{m}^{3} \mathrm{C}$ in $\mathrm{tRNA}^{\mathrm{Ser} 1}$ from the yor $240 w \Delta$ strain (Supplemental Fig. 2). In addition, both tRNA $^{\text {Thr1 }}$ and tRNA $^{\text {Ser1 }}$ isolated from the yor $240 w \Delta$ strain lacked only $\mathrm{m}^{3} \mathrm{C}$ at position 32 and retained other modifications (data not shown; pseudouridines were not analyzed).

\section{The Ado-Met binding motif in $A B P 140$ is required for $\mathrm{m}^{3} \mathrm{C}$ formation}

S. cerevisiae $A B P 140$ consists of an $\mathrm{N}$-terminal actin-binding motif, a +1 frameshift site, and the C-terminal AdoMet binding motif (Fig. 3A). When aligned with orthologs from other organisms (Fig. 3B), the C-terminal Ado-Met binding motif is conserved in budding yeast, fission yeast, Drosophila, and mammals, while the $\mathrm{N}$-terminal region is only conserved in budding yeast, including Candida glabrata and Ashbya gossypii (Fig. 3B).

At the +1 frameshift site (Fig. 3A), the sequence CTTAGGC is a slippery sequence that can promote $\sim 40 \%$ frameshift efficiency (Belcourt and Farabaugh 1990; Shah et al. 2002; Farabaugh et al. 2006). On the 0 -frame, CTT-AGG is translated as Leu-Arg. Upon +1 frameshift, CTTA-GGC is recoded to Leu-Gly. To test whether or not the frameshift event is required for $\mathrm{m}^{3} \mathrm{C}$ formation, the abp1404 strain was transformed with a plasmid vector (WT(0-frame)) harboring $A B P 140$, in which the +1 frameshift site (CTTAGGC) was replaced with the 0 -frame sequence (CTTGGC). Because $\mathrm{m}^{3} \mathrm{C}$ was efficiently formed with this construct (Fig. 4), the +1 frameshift event is not associated with $\mathrm{m}^{3} \mathrm{C}$ formation.

Abp140p localizes to actin filaments in the cell. Next, whether or not binding of Abp140p to actin filaments is required for $\mathrm{m}^{3} \mathrm{C}$ formation was examined. An $A B P 140$ mutant (delN) lacking the $\mathrm{N}$-terminal actin-binding motif was constructed (Fig. 3B), and the cellular localization of delN was analyzed by fluorescent microscopy. The delN 
A

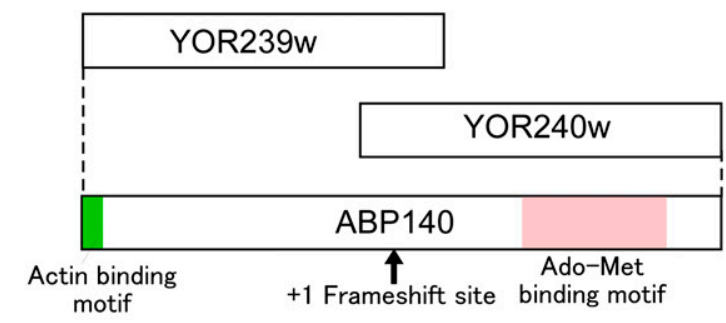

B

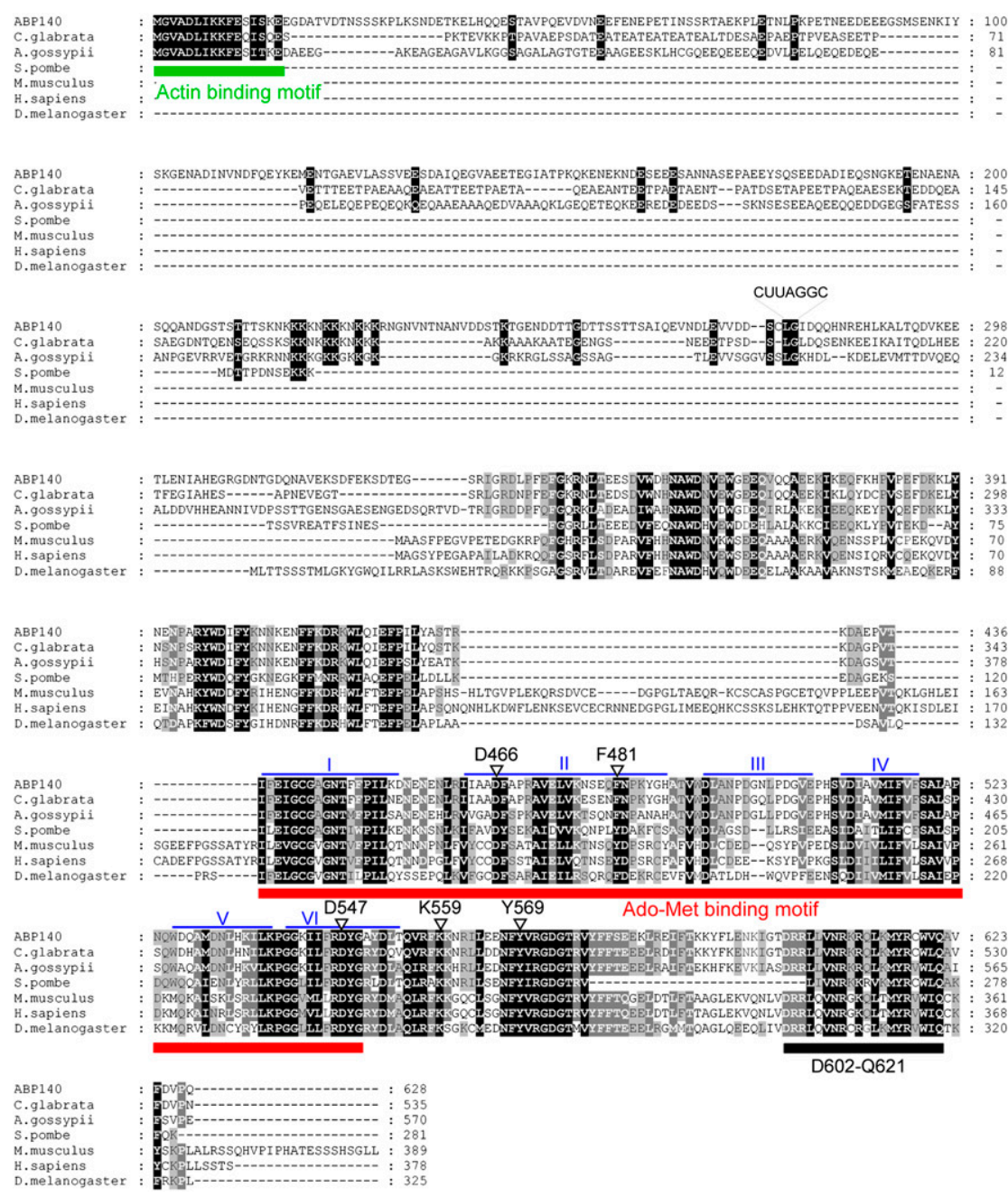

FIGURE 3. Domain structure and sequence alignment of the ABP140/TRM140 protein and its homologs. (A) Domain structure of the S. cerevisiae ABP140/TRM140 protein. Positions of YOR239w and YOR240w are shown. The actin-binding motif, +1 frameshift site, and Ado-Met binding motif are indicated. (B) Sequence alignment of $A B P 140$ and its homologs from fungi and other eukaryotes. All of these homologs were previously indicated (Farabaugh et al. 2006). The conserved actin-binding site and Ado-Met binding motif are underlined. The 7-mer slippage sequence is indicated at the +1 frameshift site. Motifs I-VI of Rossmann-fold-type class I methyltransferases are lined at the top of the sequence. The residues and C-terminal conserved region mutated in this study are indicated. Accession numbers are NC_006033.1 (Candida glabrata), NP_983532 (Ashbya gossypii), CAB76043.1 (Schizosaccharomyces pombe), BAE31989 (Mus musculus), NP_060866 (Homo sapiens), and NP_647636 (Drosophila melanogaster). actin filaments is not necessary for $\mathrm{m}^{3} \mathrm{C}$ formation in tRNAs.

ABP140 contains a conserved AdoMet binding motif in its C-terminal region. To determine the role of this motif in $\mathrm{m}^{3} \mathrm{C}$ formation, five conserved amino acids were substituted with Ala (D466A, F481A, D547A, K559A, and Y569A), and the conserved region near the $\mathrm{C}$ terminus was deleted (delD602Q621) (Fig. 3B). The abp140D strain was then transformed with each of these constructs. As shown in Figure 4, no $\mathrm{m}^{3} \mathrm{C}$ formation was observed in the D466A and delD602-Q621 mutants, and the D547A mutant showed decreased activity. Other mutants efficiently accomplished $\mathrm{m}^{3} \mathrm{C}$ formation. These data demonstrated that the conserved Ado-Met binding motif in $A B P 140$ is involved in $\mathrm{m}^{3} \mathrm{C}$ formation.

\section{In vitro reconstitution of $\mathrm{m}^{3} \mathrm{C}$ with recombinant Abp140p}

Next, we performed in vitro reconstitution of $\mathrm{m}^{3} \mathrm{C}$ using recombinant $A B P 140$ protein. A hexahistidine-tagged Abp140p was expressed in S. cerevisiae and purified using a $\mathrm{Ni}^{2+}$-chelating column. Although the molecular weight of Abp140p was calculated to be $71.5 \mathrm{kDa}$ based on its amino acid sequence, Abp140p is detected at around $140 \mathrm{kDa}$ by SDS-PAGE analysis (Asakura et al. 1998). Likewise, the recombinant Abp140p was detected at $\sim 150 \mathrm{kDa}$ due to the $19-\mathrm{kDa}$ C-terminal tag (Fig. 5A), indicating a homodimer formed through covalent linkage(s) other than disulfide bond. Purified Abp140p was confirmed by peptide mapping using LC/MS (data not shown). For in vitro reconstitution of $\mathrm{m}^{3} \mathrm{C}$, tRNA $^{\text {Thr1 }}$, and tRNA ${ }^{\text {Ser1 }}$ purified from the yor240w $\Delta$ strain were utilized as substrate tRNAs. When tRNA ${ }^{\text {Thr } 1}$ was used as a substrate, $\mathrm{m}^{3} \mathrm{C}$ was clearly introduced by the recombinant Abp140p in the presence of Ado-Met (Fig. 5B). On the other hand, tRNA ${ }^{\text {Serl }}$ was not methylated by Abp140p under the same condition as the methylation of $\mathrm{tRNA}^{\text {Thrl }}$ (Fig. $5 \mathrm{~B}$ ), indicating that some essential facmutant was diffused in cytoplasm (data not shown) and,

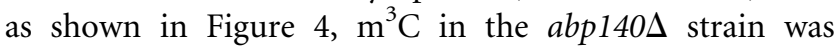
efficiently formed. Therefore, localization of Abp140p to tor(s) required for $\mathrm{m}^{3} \mathrm{C}$ formation in $\mathrm{tRNA} \mathrm{Ser}^{\text {Ser }}$ was missing. Alternatively, the order of modifications may be important for $\mathrm{m}^{3} \mathrm{C} 32$ formation in $\mathrm{tRNA} \mathrm{Serl}^{\mathrm{Ser}}$, potentially indicating 

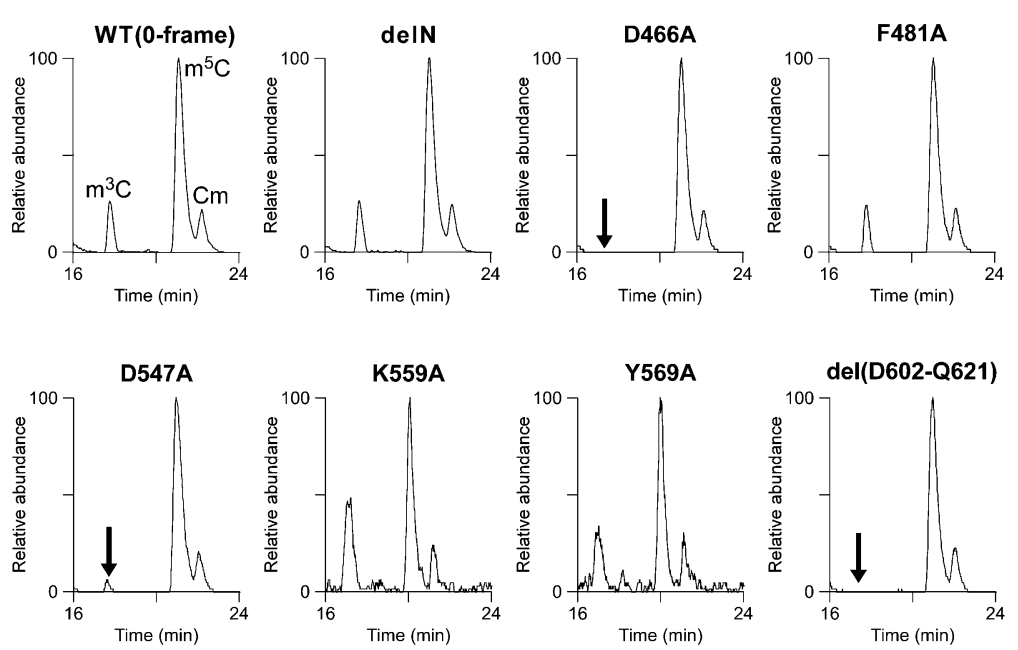

FIGURE 4. Complementation of the yor $239 w \Delta$ strain with plasmid-encoded $A B P 140$ containing various mutations. LC/MS analysis of total nucleosides isolated from yor $239 w \Delta$ strains with various $A B P 140$ constructs containing various mutations; WT( 0 -frame), delN, D466A, F481A, D547A, K559A, Y569A, and del(D602-Q621). Mass chromatograms detecting $\mathrm{MH}^{+}$ $(\mathrm{m} / \mathrm{z} 258)$ of $\mathrm{m}^{3} \mathrm{C}, \mathrm{m}^{5} \mathrm{C}$, and $\mathrm{Cm}$ are shown. Arrows indicate the retention time for $\mathrm{m}^{3} \mathrm{C}$. the $\mathrm{RNNA}^{\text {Thr1 }}$ transcript, very little $\mathrm{m}^{3} \mathrm{C}$ formation could be observed in this transcript (data not shown). This result suggested that other modifications are required for efficient $\mathrm{m}^{3} \mathrm{C} 32$ formation in tRNA ${ }^{\text {Thr1 }}$.

These results demonstrated that Abp140p is a methyltransferase for $\mathrm{m}^{3} \mathrm{C} 32$ of tRNA ${ }^{\text {Thr1 }}$. Therefore, Abp140p was designated as Trm140 p according to the preferred nomenclature.

\section{METTL2B is a human ortholog of Trm140p}

Mammalian homologs of Trm140p were searched by BLAST with ABP140 as a query. The search retrieved methyltransferase-like protein 2B (METTL2B) and methyltransferase-like protein 2 as human and mouse orthologs, respectively (Fig. 3B). Phylogenic analysis of that the introduction of other modification(s) prior to $\mathrm{m}^{3} \mathrm{C} 32$ might inhibit $\mathrm{m}^{3} \mathrm{C} 32$ formation. We then used unmodified tRNA ${ }^{\text {Serl }}$ that was transcribed in vitro using T7 RNA polymerase as a substrate for Abp140p. No $\mathrm{m}^{3} \mathrm{C} 32$ formation activity was observed in this transcript (data not shown). Some modifications in $\mathrm{tRNA}^{\text {Serl }}$ might act as positive determinant for $\mathrm{m}^{3} \mathrm{C} 32$ formation. In the case of orthologs possess the conserved Ado-Met binding motif at the C-terminal region of $A B P 140$ and lack the $\mathrm{N}$-terminal region of $A B P 140$. To examine whether METTL2B is a methyltransferase for $\mathrm{m}^{3} \mathrm{C}$ formation, short-hairpin(sh)RNA was used to knock down METTL2B mRNA in HeLa cells. Five days after transfection of shRNA, the cells were harvested these homologs were reported (Farabaugh et al. 2006). Both

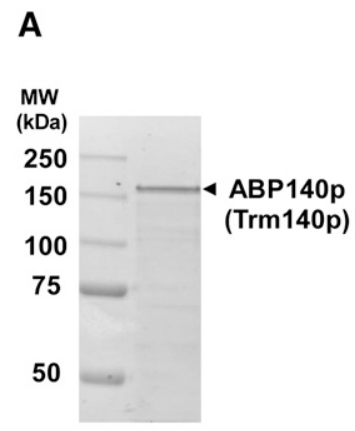

B
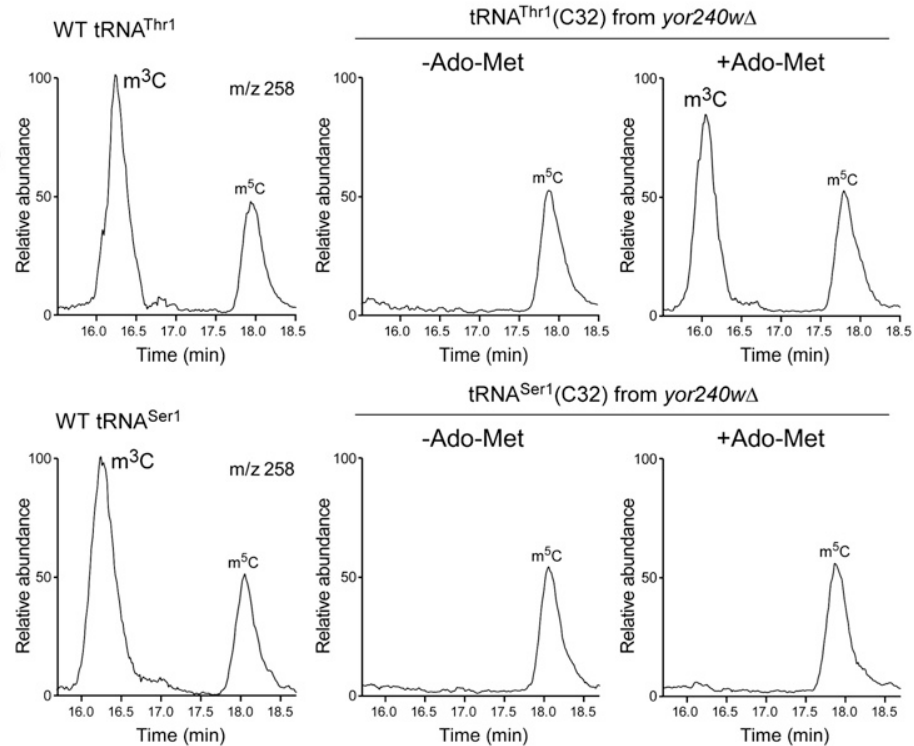

FIGURE 5. In vitro reconstitution of $\mathrm{m}^{3} \mathrm{C} 32$ by recombinant Trm140p. (A) C-terminal hexahistidine-tagged recombinant Trm140p resolved on SDS-PAGE and stained with Coomassie brilliant blue (CBB). (B) Mass chromatograms detecting $\mathrm{MH}^{+}(\mathrm{m} / \mathrm{z} 258)$ of $\mathrm{m}^{3} \mathrm{C}\left(\right.$ and $\left.\mathrm{m}^{5} \mathrm{C}\right)$ in total nucleosides from individual $\mathrm{tRNA}^{\text {Thr1 }}$ (top left) and $\mathrm{tRNA}^{\text {Ser1 }}$ (bottom left) isolated from the wild-type strain. (Right) The same mass chromatograms (m/z 258) of tRNA ${ }^{\text {Thr1 }}$ (top right) or tRNA ${ }^{\text {Ser1 }}$ (bottom right) in the absence (-Ado-Met) or presence (+Ado-Met) of Ado-Met. 
and total RNAs were extracted. LC/MS analysis revealed that the steady-state level of $\mathrm{m}^{3} \mathrm{C}$ was specifically decreased upon knock down of METTL2B (Fig. 6). Therefore, METTL2B was detemined to be a human homolog of Trm140p. However, there might be some partner proteins of METTL2B that are required to reconstitute $\mathrm{m}^{3} \mathrm{C}$ formation in tRNAs. Further investigation still needs to clarify this issue.

\section{DISCUSSION}

$A B P 140$ was first isolated as an actin-binding protein from the soluble fraction of $S$. cerevisiae (Asakura et al. 1998). Abp140p interacts with filamentous(F)-actin and has an activity to cross-link F-actin into a bundle in vitro. In the cell, Abp140p colocalizes with cortical actin patches and cytoplasmic actin filaments. However, disruption of the $A B P 140$ gene did not affect cell growth or organization of F-actin. The functional role of $A B P 140$ has been elusive. $A B P 140$ fused to GFP has been used as a reporter to visualize F-actin in the cell (Yang and Pon 2002). The $\mathrm{N}$-terminal 17-mer peptide of $A B P 140$ was found to be an actin-binding motif sufficient to mediate actin localization (Riedl et al. 2008), and a chemically modified 17-mer peptide has been developed as a versatile tool by which to visualize actin dynamics in the cell (Riedl et al. 2008). Although $A B P 140$ shows a functional relevance to F-actin, we found no significant importance for actin localization in $\mathrm{m}^{3} \mathrm{C}$ formation, as no effect on $\mathrm{m}^{3} \mathrm{C}$ formation was observed upon deletion of the $\mathrm{N}$-terminal actin-binding motif. In addition, in an in vitro $\mathrm{m}^{3} \mathrm{C}$ formation in tRNA ${ }^{\mathrm{Thr} 1}$ catalyzed by recombinant Trm140p, the addition of F-actin to the reaction mixture did not alter of $\mathrm{m}^{3} \mathrm{C}$-forming activity (data
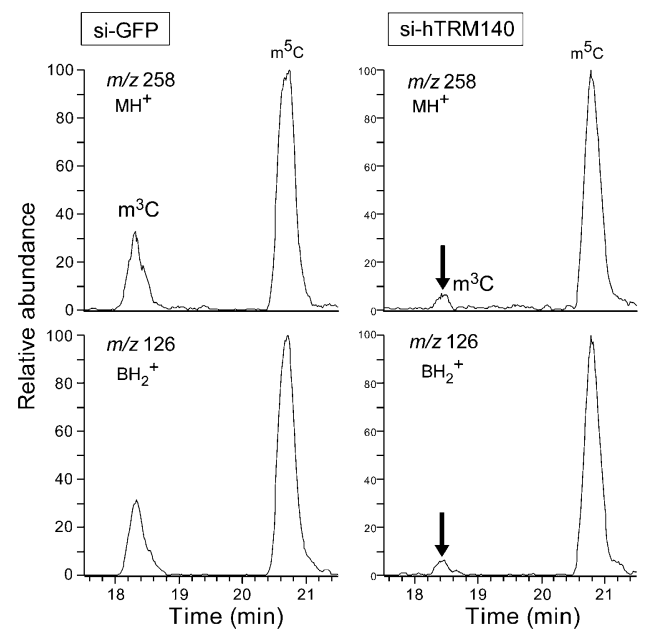

FIGURE 6. Knockdown of human TRM140 decreases $\mathrm{m}^{3} \mathrm{C}$ formation. LC/MS nucleoside analysis of RNA from cells treated with shRNAs targeting GFP (left) and hTRM140 (right). (Top, bottom) Mass chromatograms detecting $\mathrm{MH}^{+}(\mathrm{m} / \mathrm{z} 258)$ and $\mathrm{BH}^{2+}(\mathrm{m} / \mathrm{z} 126)$ of $\mathrm{m}^{3} \mathrm{C}$ and $\mathrm{m}^{5} \mathrm{C}$, respectively. not shown). Taken together, the actin-binding activity of Trm140p appears to be independent of $\mathrm{m}^{3} \mathrm{C}$ catalytic activity.

From the viewpoint of tRNA biogenesis, actin localization of Trm140p might be involved in hierarchical modification of tRNAs. Most of the modifications are introduced into tRNA precursors in the nucleus (Knapp et al. 1978; Phizicky and Hopper 2010), since many tRNAmodifying enzymes are localized there. Some modifications, however, can be introduced into tRNAs after export to the cytoplasm (Murthi et al. 2010). Considering the actin localization of $\operatorname{Trm} 140 \mathrm{p}, \mathrm{m}^{3} \mathrm{C}$ formation should occur in the cytoplasm. In fact, $\mathrm{tRNA}^{\mathrm{Thr} 1}$ and $\mathrm{tRNA}^{\text {Ser1 }}$ isolated from the trm140د strain contained most of the modifications other than $\mathrm{m}^{3} \mathrm{C} 32$ (data not shown, pseudouridines were not analyzed), indicating that $\mathrm{m}^{3} \mathrm{C} 32$ is introduced at the late step of tRNA biogenesis in the cytoplasm. This is consistent with our observation that the unmodified tRNA ${ }^{\text {Thr1 }}$ transcript was not as good a substrate for Trm140p, while

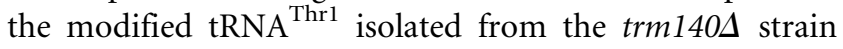
was efficiently methylated by Trm140p. Hence, Trm140p might monitor tRNA maturation in the cytoplasm by recognizing other tRNA modifications.

Mass spectrometric analysis of individual tRNAs isolated from the trm140د strain revealed that TRM140 is involved in $\mathrm{m}^{3} \mathrm{C}$ formation in both $\mathrm{tRNA} \mathrm{Thr}^{\mathrm{Th} 1}$ and $\mathrm{tRNA} \mathrm{Ar}^{\text {Ser1 }}$. However, tRNA $^{\text {Ser1 }}$ was not methylated by recombinant Trm140p in vitro under the same conditions that allow it to methylate tRNA $^{\text {Thr1 }}$ (Fig. 5B). This suggests that there might be partner protein(s) for Trm140p that are required for it to recognize tRNA $^{\text {Serl }}$ specifically. According to interactome analysis (Stark et al. 2011), there are 22 proteins that can associate with Abp140p (Trm140p). In addition, actin-binding proteins might also be candidates for partners of Trm140p. Further study will be necessary to clarify how tRNA ${ }^{\text {Serl }}$ is methylated by Trm140p. Otherwise, the order of modifications might be important for $\mathrm{m}^{3} \mathrm{C} 32$ formation in $\mathrm{tRNA}^{\text {Ser1 }}$. Considering efficient $\mathrm{m}^{3} \mathrm{C} 32$ formation in $\mathrm{tRNA}^{\text {Thr1 }}$ isolated from trm140د strain, there might be some modifications that act as positive determinants for $\mathrm{m}^{3} \mathrm{C} 32$ formation in tRNA ${ }^{\text {Ser1 }}$.

Because position 32 of tRNA has an important role in accurate codon recognition, $\mathrm{m}^{3} \mathrm{C} 32$ formation in $\mathrm{RNA}^{\text {Thr1 }}$ or tRNA ${ }^{\text {Serl }}$ might play a role in modulating codon recognition and translational efficiency. No obvious phenotype of trm1404 has been detected (Asakura et al. 1998), which indicates that this modification has no critical effect on translation. Recently, a chemical genetic approach was applied to characterize $S$. cerevisiae gene-deletion strains (Alamgir et al. 2010). In this study, a trm140د strain showed increased sensitivity to neomycin. Neomycin is an aminoglycoside antibiotic that targets the A-site decoding center on the small subunit of the ribosome. This result implies that the lack of $\mathrm{m}^{3} \mathrm{C} 32$ might affect the A-site decoding in the presence of neomycin. In addition, it will be of value to test this strain under various stress conditions, including 
nutrient deprivation, response to reactive oxygen species, and chemicals, to observe other phenotypes related to $A B P 140$.

Another intriguing feature of $A B P 140 / T R M 140$ is the presence of an internal frameshift site (Asakura et al. 1998) at which the slippery sequence, CUUAGGC, can promote a 40\% frameshift frequency (Belcourt and Farabaugh 1990; Shah et al. 2002; Farabaugh et al. 2006). This sequence was first identified as the +1 frameshift site of the TYB gene of the Ty1 retrotransposon (Kawakami et al. 1993; Voytas and Boeke 1993). On the 0-frame, the CUU and AGG codons are decoded by tRNA ${ }^{\text {Leu }}$ and $\mathrm{tRNA}^{\text {Arg }}$, respectively. However, the AGG codon frequently causes translational pausing at the A-site on the ribosome due to the low availability of tRNA ${ }^{A r g}$ encoded by a single gene. During pausing, at the P-site, tRNA ${ }^{\text {Leu }}$ bearing a UAG anticodon that recognizes the CUU codon, slips toward the +1 frame to base pair with the UUA codon. Then, the AGG codon for Arg is recoded as a GGC codon for Gly at the A site. Since replacing this frameshift site with the 0 -frame sequence did not affect the expression of Trm140p and $\mathrm{m}^{3} \mathrm{C}$ formation (Fig. 4), the functional importance of this recoding event is still enigmatic. If $\mathrm{m}^{3} \mathrm{C} 32$ formation in tRNA ${ }^{\text {Thr1 }}$ or tRNA $^{\text {Serl }}$ modulates its capacity for codon recognition and translational efficiency, it can be speculated that expression of Trm140p might be regulated by the efficiency of +1 frameshifing in its mRNA mediated by tRNA ${ }^{\text {Thr1 }}$ or tRNA $^{\text {Ser1 }}$, with altered levels of $\mathrm{m}^{3} \mathrm{C}$ modification at position 32. However, these tRNAs are not directly involved in the frameshift event. In addition, the frameshift site is only conserved in very close relatives of $S$. cerevisiae (Fig. 3B). Even if such regulation exists, its functional importance will be limited.

ABP140/TRM140 has a conserved Ado-Met binding motifs in its C-terminal region (Fig. 3A,B). Sequence alignment based on structural motif revealed that the Ado-Met binding motif in this protein belongs to a large family of Rossmann-fold type class I methyltransferases that consist of six conserved motifs (motifs I-VI) (Fig. 3B; Kozbial and Mushegian 2005). In motif II, a highly conserved acidic residue (Asp or Glu) corresponds to Asp466 in Trm140p. When Asp466 was replaced with $\mathrm{Ala}$, no $\mathrm{m}^{3} \mathrm{C}$ formation was observed (Fig. 4). According to structural analyses, this conserved Asp is located at the C terminus of $\beta$-strand 2 in Rossmann-fold-type class I methyltransferases (Martin and McMillan 2002; Kozbial and Mushegian 2005). In the crystal structure of rat glycine $\mathrm{N}$-methyltransferase (GNMT) (Takata et al. 2003), the equivalent residue, Asp85, directly interacts with the $2^{\prime}$ and $3^{\prime}$ hydroxyl groups of ribose in Ado-Met via hydrogen bonds. In E. coli, when Asp277, which corresponds to Asp466 in Trm140p, was mutated in RsmC, a methyltransferase for $\mathrm{N}^{2}$-methylguanosine at 1207 in 16S rRNA, its binding affinity for Ado-Met was lost (Sunita et al. 2007). This strongly suggests that Asp466 in Trm140p is directly involved in Ado-Met binding. Mutation of Asp547 to Ala decreased $\mathrm{m}^{3} \mathrm{C}$ formation in the cell (Fig. 4). This Asp is not a conserved residue in motif VI of class I methyltransferases and might be involved in tRNA recognition. In addition, no activity of Trm140p was observed following deletion of the conserved C terminus (D602-Q621) (Fig. 4). This indicated that this region might be important for tRNA binding or protein folding. A series of mutation studies and kinetic analyses will be necessary to further characterize this enzyme. Moreover, it will also be worth attempting to obtain the crystal structure of Trm140p complexed with tRNA ${ }^{\text {Thr1 }}$.

\section{MATERIALS AND METHODS}

\section{Strains, media, and plasmids}

S. cerevisiae wild-type and deletion strains used in this study were obtained from EUROSCARF: the BY4742 (Mat $\alpha$; his3 4 1; leu2 $\Delta 0$;

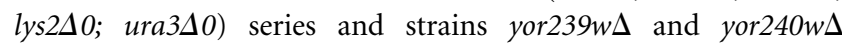
(BY4742, YOR239w::kanMX4, and YOR240w::kanMX4). Yeast strain overexpressing hexahistidine-tagged Abp140p (YSC38699515832, Y258; Mat a; pep $4 \Delta 3$; his $4 \Delta 580$; ura3 $\Delta 53$; leu2 $\Delta 3$;/ pABP140) was obtained from Open Biosystems. To construct the abp $140 \Delta$ strain, the ABP140 ORF was replaced with URA3 by PCR-based gene deletion (Baudin et al. 1993). The PCR product was amplified from pCgURA3 (BYP1806 obtained from NBRP) as a template using the primers, $5^{\prime}$-ccaatacaattgtataccaaataagctattaca aattgatttaaatcgaggtcgacggtatc $-3^{\prime}$ and $5^{\prime}$-cttgttttatgatgagagaggaggtg gtacttgtctcagaacttccgctctagaactagtggatc- $3^{\prime}$. The $\Delta p e p 4$ strain obtained from EUROSCARF [BY4741; MATa; his3 $\Delta$ 1; leu2 $\Delta 0$; met15 $\Delta 0$; ura3 $\Delta$ 0; pep4(YPL154c)::kanMX4] was transformed with the PCR product. Ura+ transformants were selected to obtain the abp $140 \Delta$ strain. Yeast strains were grown in rich medium (YPD: $2 \%$ peptone, $1 \%$ yeast extract, and $2 \%$ glucose) or in synthetic complete medium (SC: $0.67 \%$ yeast nitrogen base without amino acids, $0.5 \%$ casamino acid, and $2 \%$ glucose) supplemented with auxotrophic nutrients as specified. The plasmid pKT10-GAL-HAABP140 (Asakura et al. 1998) was used for expressing Abp140p in yeast cells.

\section{Ribonucleome analysis}

The procedure was performed as described previously (Noma et al. 2006; Suzuki et al. 2007). Briefly, yeast strains were grown in $5 \mathrm{~mL}$ of YPD in 24 -well deep well plates at $30^{\circ} \mathrm{C}$ and the cells were harvested during $\log$ phase growth $\left(\mathrm{OD}_{660}=1.5-2.0\right)$. Total RNAs were extracted from the cells of each gene-deletion strain by the phenolchloroform method. Approximately $20 \mu \mathrm{g}$ of total RNA was digested to nucleosides and analyzed by LC/MS. Absence of a specific modified nucleoside was monitored on the mass chromatogram for each strain.

\section{Isolation and purification of individual tRNAs from yeast}

Reciprocal circulating chromatography was used to isolate individual tRNAs (Miyauchi et al. 2007). The sequences of the 3'biotinylated DNA probes complementary to yeast tRNA ${ }^{\text {Thr1 }}$ and tRNA ${ }^{\text {Ser1 }}$ were $5^{\prime}$-tgcttccaatcggatttgaaccgatgatct- $3^{\prime}$ and $5^{\prime}$-cgacacc agcaggatttgaaccagcgcggg- $3^{\prime}$, respectively. 


\section{Mass spectrometry}

RNA fragments digested by RNase $T_{1}$ were analyzed by LC/MS using ion-trap MS according to a previously described method (Kaneko et al. 2003; Noma et al. 2006), with slight modifications. Purified tRNA ${ }^{\text {Thrl }}$ and tRNA $^{\text {Serl }}(2.5 \mu$ g each) were subjected to digestion by RNase $\mathrm{T}_{1}$ (Seikagaku corporation; $0.6 \mathrm{U}$ ) for $30 \mathrm{~min}$ at $37^{\circ} \mathrm{C}$ in a buffer of $10 \mathrm{mM} \mathrm{NH}_{4} \mathrm{OAc}(\mathrm{pH}$ 5.3). The hydrolysates were separated by ODS column chromatography (Xterra MS C18 $2.5 \mu \mathrm{m}, 2.1 \times 50 \mathrm{~mm}$, Waters). The solvent system consisted of 0.4 M 1,1,1,3,3,3-hexafluoro-2-propanol ( $\mathrm{pH} 7.0$, adjusted with triethylamine) in $\mathrm{H}_{2} \mathrm{O}$ (Solvent A) and 50\% methanol (Solvent B) with the following gradients: $5 \% \mathrm{~B}$ for $0-5 \mathrm{~min}, 5 \%-95 \% \mathrm{~B}$ for 5-35 min, $95 \%$ B for $35-40 \mathrm{~min}, 95 \%-5 \%$ B for $40-42 \mathrm{~min}$, and $5 \%$ B for $42-60 \mathrm{~min}$. The chromatographic effluent was directly conducted to the ESI source to ionize the separated RNA fragments, which were then analyzed on an LCQ DUO ion-trap mass spectrometer (ThermoElectron). Negative ions were scanned over an m/z range of from 620 to 2000 throughout the separation.

\section{Expression and purification of the recombinant proteins}

Yeast expressing hexahistidine-tagged Abp140p was grown at $30^{\circ} \mathrm{C}$ in YPD. Expression of recombinant proteins was induced by the addition of $2 \%$ galactose. After cultivation for $20 \mathrm{~h}$, cells were harvested and washed with $\mathrm{ddH}_{2} \mathrm{O}$ and then resuspended in lysis buffer (20 mM HEPES-KOH at $\mathrm{pH}$ 7.6, $10 \mathrm{mM} \mathrm{KOAc,} 2 \mathrm{mM}$ $\mathrm{Mg}(\mathrm{OAc})_{2}, 1 \mathrm{mM}$ dithiothreitol [DTT] and protease inhibitor cocktail [Roche]) and disrupted by five passes through a French press (Thermo Fischer Scientific). The cell lysate was cleared by ultracentrifugation at $100,000 \mathrm{~g}$ for $1.5 \mathrm{~h}$ at $4^{\circ} \mathrm{C}$. The hexahistidine-tagged protein was purified with the AKTA purifier chromatography system (GE Healthcare) using a Hi-Trap chelating HP column (GE Healthcare). Briefly, the column was washed once with $\mathrm{ddH}_{2} \mathrm{O}$ and $10 \mathrm{~mL}$ of $0.1 \mathrm{M} \mathrm{NiSO}_{4}$ was loaded on the column, followed by additional washes with $\mathrm{ddH}_{2} \mathrm{O}$. The column was then equilibrated with wash buffer $(50 \mathrm{mM}$ HEPES-KOH at $\mathrm{pH}$ 7.6, $100 \mathrm{mM} \mathrm{KCl}, 10 \mathrm{mM} \mathrm{MgCl}_{2}, 7 \mathrm{mM} \beta$-mercaptoethanol, and a protease inhibitor cocktail), and the cleared cell lysate was loaded onto the column and washed with $25-50 \mathrm{~mL}$ of wash buffer. The His-tagged proteins were eluted from the column with a linear-gradient of imidazole $(50-450 \mathrm{mM})$ in wash buffer, and the eluted fractions were analyzed by SDS-PAGE. Fractions containing full-length Abp140p were pooled and dialyzed against

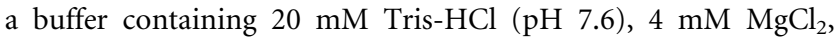
$55 \mathrm{mM} \mathrm{NaCl}$, and $1 \mathrm{mM}$ DTT.

\section{In vitro reconstitution of $\mathrm{m}^{3} \mathrm{C}$ using recombinant Trm140p}

The reaction mixture $(10 \mu \mathrm{L})$ contained $50 \mathrm{mM}$ Tris- $\mathrm{HCl}(\mathrm{pH} 8.0)$, $0.5 \mathrm{mM}$ DTT, $10 \mathrm{mM} \mathrm{MgCl}_{2}, 1 \mathrm{mM}$ spermidine, $2 \mu \mathrm{g}$ of tRNA ${ }^{\text {Thrl }}$ or tRNA ${ }^{\text {Ser1 }}$ obtained from yor $240 w \Delta$ strain, and $1.4 \mu \mathrm{M}$ recombinant Abp140p, in the presence or absence of $0.5 \mathrm{mM}$ Ado-Met. The reactions were incubated for $1 \mathrm{~h}$ at $30^{\circ} \mathrm{C}$. After incubation, the reaction was stopped by the addition of neutralized phenol. RNA $^{\text {Thr1 }}$ or tRNA ${ }^{\text {Serl }}$ was extracted and precipitated by ethanol and then digested by nuclease P1 and bacterial alkaline phosphatase. RNA nucleoside analysis by LC/MS was carried out as described above.

\section{RNA interference}

Short hairpin RNAs (shRNAs) targeting hTrm140 and GFP (as a control) were designed by siExplorer and prepared as described (Katoh and Suzuki 2007). The sense strands of shRNAs for hTrm140 and GFP were 5'-GGAAGCAACUGACAAUGUA-3' (shRNA-ABP140-1) and 5'-GGCACAAGCUGGAGUACAA-3', respectively. The shRNAs were introduced into HeLa cells using Lipofectamine RNAiMAX (Invitrogen) as described previously (Katoh et al. 2009). Five days after transfection, the cells were harvested and total RNAs were extracted using TRIzol (Invitrogen). The steady-state level of hTrm140 mRNA was then measured by real-time RT-PCR using the primers $5^{\prime}$-ctcagcttcggtttaaaaaaggt- $3^{\prime}$ and $5^{\prime}$-gtgtccagttcctcttgtgtg- $3^{\prime}$, which confirmed that the level of hTrm140 mRNA was decreased to $8.8 \%$ of that of control cells transfected with GFP shRNA.

\section{Site-directed mutagenesis}

Site-directed mutagenesis of $A B P 140$ was carried out in the plasmid pKT10-GAL-HA-ABP140 (Asakura et al. 1998) with QuikChange Site-Directed Mutagenesis (Stratagene) according to the manufacturer's instructions. The introduced mutation in each construct was confirmed by DNA sequencing. The following pairs of oligonucleotides were used to create each mutation:

WT(0-frame), 5' -gttgatgactcttgtctaggcattgatcaacagca- $3^{\prime}$ and $5^{\prime}$-tgc tgttgatcaatgcctagacaagagtcatcaac- $3^{\prime}$;

delN, 5' -gtaccggatccggtaccatgggcgatgctaccgttgatac- $3^{\prime}$ and $5^{\prime}$-gtatc aacggtagcatcgeccatggtaccggatccggtac- $3^{\prime}$;

D466A, 5' -gaggataatagccgcagcttttgctccaagagccg- $3^{\prime}$ and $5^{\prime}$-cggctctt ggagcaaaagctgcggctattatcctc- $3^{\prime}$;

F481A, 5' -ttaaaaattctgaacaggccaaccccaagtacggcc- $3^{\prime}$ and $5^{\prime}$-ggccgta cttggggttggcctgttcagaatttttaa- $3^{\prime}$;

D547A, $5^{\prime}$-taagatcatatttcgtgcttacggtgcatatgatt- $3^{\prime}$ and $5^{\prime}$-aatcatatgc accgtaagcacgaaatatgatctta- $3^{\prime}$;

K599A, 5' -taactcaagttagattcgcaaagaacagaatcctag- $3^{\prime}$ and $5^{\prime}$-ctaggatt ctgttctttgcgaatctaacttgagtta- $3^{\prime}$;

Y569A, $5^{\prime}$-tcctagaagagaacttcgccgttagaggtgatggta- $3^{\prime}$ and $5^{\prime}$-taccatca cctctaacggcgaagttctcttctagga- $3^{\prime}$;

del(D602-Q621), 5' -tggaaaataaaattggaactgctgtgtttgacgttcctca-3' and $5^{\prime}$-tgaggaacgtcaaacacagcagttccaattttattttcca-3'.

\section{SUPPLEMENTAL MATERIAL}

Supplemental material is available for this article.

\section{ACKNOWLEDGMENTS}

We thank the members of the Suzuki laboratory, in particular Y. Sakaguchi, K. Miyauchi, and S. Kimura, for their technical support and many fruitful discussions. This work was supported by Grants-in-Aid for Scientific Research on Priority Areas from the Ministry of Education, Science, Sports, and Culture of Japan (to T.S.), by a JSPS Fellowship for Japanese Junior Scientists (to A.N.), and by a grant from the New Energy and Industrial Technology Development Organization (NEDO) (to T.S.).

Received January 31, 2011; accepted March 9, 2011. 


\section{REFERENCES}

Agris PF, Vendeix FA, Graham WD. 2007. tRNA's wobble decoding of the genome: 40 years of modification. J Mol Biol 366: 1-13.

Alamgir M, Erukova V, Jessulat M, Azizi A, Golshani A. 2010. Chemical-genetic profile analysis of five inhibitory compounds in yeast. BMC Chem Biol 10: 6. doi: 10.1186/1471-6769-10-6.

Asakura T, Sasaki T, Nagano F, Satoh A, Obaishi H, Nishioka H, Imamura H, Hotta K, Tanaka K, Nakanishi H, et al. 1998. Isolation and characterization of a novel actin filament-binding protein from Saccharomyces cerevisiae. Oncogene 16: 121-130.

Baudin A, Ozier-Kalogeropoulos O, Denouel A, Lacroute F, Cullin C. 1993. A simple and efficient method for direct gene deletion in Saccharomyces cerevisiae. Nucleic Acids Res 21: 3329-3330.

Belcourt MF, Farabaugh PJ. 1990. Ribosomal frameshifting in the yeast retrotransposon Ty: tRNAs induce slippage on a 7 nucleotide minimal site. Cell 62: 339-352.

Bjork GR. 1995. Biosynthesis and function of modified nucleosides. In tRNA: Structure, biosynthesis and function. Vol. 50, pp. 165-205. ASM Press, Herndon, VA.

Cantara WA, Crain PF, Rozenski J, McCloskey JA, Harris KA, Zhang X, Vendeix FA, Fabris D, Agris PF. 2011. The RNA Modification Database, RNAMDB: 2011 update. Nucleic Acids Res 39: D195-D201.

Curran JF. 1998. Modified nucleosides in translation. In Modification and editing of RNA: The alteration of RNA structure and function. (ed. $\mathrm{H}$ Grosjean, R Benne), pp. 493-516. ASM press, Washington, DC.

Dunin-Horkawicz S, Czerwoniec A, Gajda MJ, Feder M, Grosjean H, Bujnicki JM. 2006. MODOMICS: a database of RNA modification pathways. Nucleic Acids Res 34: D145-D149.

Farabaugh PJ, Kramer E, Vallabhaneni H, Raman A. 2006. Evolution of +1 programmed frameshifting signals and frameshift-regulating tRNAs in the order Saccharomycetales. J Mol Evol 63: 545-561.

Guldener U, Munsterkotter M, Kastenmuller G, Strack N, van Helden J, Lemer C, Richelles J, Wodak SJ, Garcia-Martinez J, Perez-Ortin JE, et al. 2005. CYGD: the comprehensive yeast genome database. Nucleic Acids Res 33: D364-D368.

Hall RH. 1963. Isolation of 3-methyluridine and 3-methylcytidine from solubleribonucleic acid. Biochem Biophys Res Commun 12: 361-364.

Ikeuchi Y, Kimura S, Numata T, Nakamura D, Yokogawa T, Ogata T, Wada T, Suzuki T, Suzuki T. 2010. Agmatine-conjugated cytidine in a tRNA anticodon is essential for AUA decoding in archaea. Nat Chem Biol 6: 277-282.

Iwanami Y, Brown GM. 1968. Methylated bases of ribosomal ribonucleic acid from HeLa cells. Arch Biochem Biophys 126: 8-15.

Juhling F, Morl M, Hartmann RK, Sprinzl M, Stadler PF, Putz J. 2009. tRNAdb 2009: compilation of tRNA sequences and tRNA genes. Nucleic Acids Res 37: D159-D162.

Kaneko T, Suzuki T, Kapushoc ST, Rubio MA, Ghazvini J, Watanabe K, Simpson L, Suzuki T. 2003. Wobble modification differences and subcellular localization of tRNAs in Leishmania tarentolae: implication for tRNA sorting mechanism. EMBO J 22: 657-667.

Katoh T, Suzuki T. 2007. Specific residues at every third position of siRNA shape its efficient RNAi activity. Nucleic Acids Res 35: e27. doi: $10.1093 / \mathrm{nar} / \mathrm{gkl} 100$.

Katoh T, Sakaguchi Y, Miyauchi K, Suzuki T, Kashiwabara S, Baba T, Suzuki T. 2009. Selective stabilization of mammalian microRNAs by $3^{\prime}$ adenylation mediated by the cytoplasmic poly(A) polymerase GLD-2. Genes Dev 23: 433-438.

Kawakami K, Pande S, Faiola B, Moore DP, Boeke JD, Farabaugh PJ, Strathern JN, Nakamura Y, Garfinkel DJ. 1993. A rare tRNA-Arg(CCU) that regulates Tyl element ribosomal frameshifting is essential for Tyl retrotransposition in Saccharomyces cerevisiae. Genetics 135: 309-320.

Knapp G, Beckmann JS, Johnson PF, Fuhrman SA, Abelson J. 1978. Transcription and processing of intervening sequences in yeast tRNA genes. Cell 14: 221-236.

Korostelev A, Noller HF. 2007. The ribosome in focus: new structures bring new insights. Trends Biochem Sci 32: 434-441.

Kozbial PZ, Mushegian AR. 2005. Natural history of S-adenosylmethioninebinding proteins. BMC Struct Biol 5: 19. doi: 10.1186/1472-6807-5-19.
Lustig F, Boren T, Claesson C, Simonsson C, Barciszewska M, Lagerkvist U. 1993. The nucleotide in position 32 of the tRNA anticodon loop determines ability of anticodon UCC to discriminate among glycine codons. Proc Natl Acad Sci 90: 3343-3347.

Maden BE, Salim M. 1974. The methylated nucleotide sequences in HELA cell ribosomal RNA and its precursors. J Mol Biol 88: 133-152.

Martin JL, McMillan FM. 2002. SAM (dependent) I AM: the S-adenosylmethionine-dependent methyltransferase fold. Curr Opin Struct Biol 12: 783-793.

Miyauchi K, Ohara T, Suzuki T. 2007. Automated parallel isolation of multiple species of non-coding RNAs by the reciprocal circulating chromatography method. Nucleic Acids Res 35: e24. doi: 10.1093/ nar/gkl1129.

Murakami H, Ohta A, Suga H 2009. Bases in the anticodon loop of tRNA(Ala)(GGC) prevent misreading. Nat Struct Mol Biol 16: 353-358.

Murthi A, Shaheen HH, Huang HY, Preston MA, Lai TP, Phizicky EM, Hopper AK. 2010. Regulation of tRNA bidirectional nuclearcytoplasmic trafficking in Saccharomyces cerevisiae. Mol Biol Cell 21: 639-649.

Nasvall SJ, Nilsson K, Bjork GR. 2009. The ribosomal grip of the peptidyl-tRNA is critical for reading frame maintenance. J Mol Biol 385: $350-367$.

Noma A, Kirino Y, Ikeuchi Y, Suzuki T. 2006. Biosynthesis of wybutosine, a hyper-modified nucleoside in eukaryotic phenylalanine tRNA. EMBO J 25: 2142-2154.

Noma A, Sakaguchi Y, Suzuki T. 2009. Mechanistic characterization of the sulfur-relay system for eukaryotic 2-thiouridine biogenesis at tRNA wobble positions. Nucleic Acids Res 37: 1335-1352.

Olejniczak M, Uhlenbeck OC. 2006. tRNA residues that have coevolved with their anticodon to ensure uniform and accurate codon recognition. Biochimie 88: 943-950.

Olson MV, Page GS, Sentenac A, Piper PW, Worthington M, Weiss RB, Hall BD. 1981. Only one of two closely related yeast suppressor tRNA genes contains an intervening sequence. Nature 291: 464-469.

Phizicky EM, Hopper AK. 2010. tRNA biology charges to the front. Genes Dev 24: 1832-1860.

Riedl J, Crevenna AH, Kessenbrock K, Yu JH, Neukirchen D, Bista M, Bradke F, Jenne D, Holak TA, Werb Z, et al. 2008. Lifeact: a versatile marker to visualize F-actin. Nat Methods 5: 605-607.

Shah AA, Giddings MC, Parvaz JB, Gesteland RF, Atkins JF, Ivanov IP. 2002. Computational identification of putative programmed translational frameshift sites. Bioinformatics 18: 1046-1053.

Soma A, Ikeuchi Y, Kanemasa S, Kobayashi K, Ogasawara N, Ote T, Kato J, Watanabe K, Sekine Y, Suzuki T. 2003. An RNA-modifying enzyme that governs both the codon and amino acid specificities of isoleucine tRNA. Mol Cell 12: 689-698.

Stark C, Breitkreutz BJ, Chatr-Aryamontri A, Boucher L, Oughtred R, Livstone MS, Nixon J, Van Auken K, Wang X, Shi X, et al. 2011. The BioGRID Interaction Database: 2011 update. Nucleic Acids Res 39: D698-D704.

Sunita S, Purta E, Durawa M, Tkaczuk KL, Swaathi J, Bujnicki JM, Sivaraman J. 2007. Functional specialization of domains tandemly duplicated within 16S rRNA methyltransferase RsmC. Nucleic Acids Res 35: 4264-4274.

Suzuki T. 2005. Biosynthesis and function of tRNA wobble modifications. In Fine-tuning of RNA functions by modification and editing, Vol. 12, pp. 24-69. Springer-Verlag, New York.

Suzuki T, Ikeuchi Y, Noma A, Suzuki T, Sakaguchi Y. 2007. Mass spectrometric identification and characterization of RNA-modifying enzymes. Methods Enzymol 425: 211-229.

Takata Y, Huang Y, Komoto J, Yamada T, Konishi K, Ogawa H, Gomi T, Fujioka M, Takusagawa F. 2003. Catalytic mechanism of glycine N-methyltransferase. Biochemistry 42: 8394-8402.

Voytas DF, Boeke JD. 1993. Yeast retrotransposons and tRNAs. Trends Genet 9: 421-427.

Weissenbach J, Kiraly I, Dirheimer G. 1977. Primary structure of tRNA Thr 1a and b from brewer's yeast. Biochimie 59: 381-391.

Yang HC, Pon LA. 2002. Actin cable dynamics in budding yeast. Proc Natl Acad Sci 99: 751-756. 

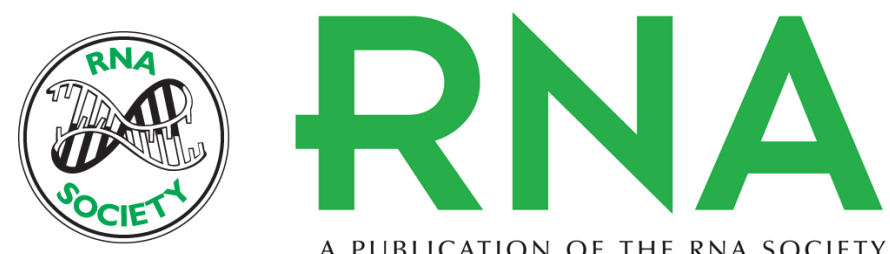

A PUBLICATION OF THE RNA SOCIETY

\section{Actin-binding protein ABP140 is a methyltransferase for 3-methylcytidine at position 32 of tRNAs in Saccharomyces cerevisiae}

Akiko Noma, Sanghyun Yi, Takayuki Katoh, et al.

RNA 2011 17: 1111-1119 originally published online April 25, 2011

Access the most recent version at doi:10.1261/rna.2653411

\section{Supplemental http://rnajournal.cshlp.org/content/suppl/2011/04/01/rna.2653411.DC1 \\ Material}

Related Content

A domain of the actin binding protein Abp140 is the yeast methyltransferase responsible for 3-methylcytidine modification in the tRNA anti-codon loop Sonia D'Silva, Steffen J. Haider and Eric M. Phizicky

RNA June , 2011 17: 1100-1110

References This article cites 44 articles, 6 of which can be accessed free at:

http://rnajournal.cshlp.org/content/17/6/1111.full.html\#ref-list-1

Articles cited in:

http://rnajournal.cshlp.org/content/17/6/1111.full.html\#related-urls

\section{License}

Email Alerting Receive free email alerts when new articles cite this article - sign up in the box at the Service top right corner of the article or click here.

\section{|||||||| Providing Precise Solutions for your research.}

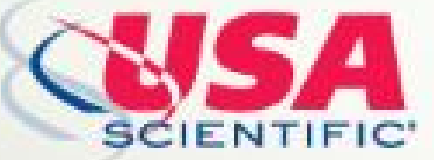

To subscribe to $R N A$ go to:

http://rnajournal.cshlp.org/subscriptions 